\title{
The Synthesis of Phage and Host DNA in the Establishment of Lysogeny'
}

\author{
HAMILTON O. SMITH AND MYRON LEVINE \\ Department of Human Genetics and The Lawrence D. Buhl Research Center for Human \\ Genetics, University of Michigan, Ann Arbor, Michigan \\ Accepted December 29,1964
}

\begin{abstract}
A method of extraction is described which prevents excessive fragmentation of bacterial DNA. The larger bacterial DNA can then be separated from the phage DNA on sucrose gradients. The relative amounts of phage and host DNA made at various times during infection of Salmonella typhimurium with phage P22 leading to lysogeny have been determined. Phage-specific DNA synthesis begins at about 4 minutes, continues to increase for $2-4$ minutes, and then decreases until completc ropression is attained at 16 minutes. Autonomous phage DNA synthesis remains repressed from then on. Bacterial-specifie synthesis proceeds at a decreasing rate until about 16 minutes, when almost complete inhibition is reached. When DNA synthesis recovers in the infected cells, only host-specific material is made. A new species of DNA, which is made only when phage DNA is synthesized, has been detected. The possible implications of these findings in the understanding of the lysogenic interaction is discussed.
\end{abstract}

\section{INTRODUCTION}

Two sequential repressions in the rate of DNA synthesis occur during the establishment of lysogeny in Salmonella typhimurium infected with the temperate phage P22 (Smith and Levine, 1964). The purpose of this report is to differentiate the kind of DNA, phage or bacterial, synthesized at various times during the course of such an infection. To accomplish this, advantage is taken of the large size differences of the phage and host DNA molecules. A simple extraction procedure is described which prevents excessive fragmentation of bacterial DNA, enabling the separation of the high molecular weight host DNA from the smaller phage DNA by zone centrifugation through a sucrose gradient.

\section{MATERIALS AND METHODS}

Phage and bacterial strains. The wild-type $\left(c^{+}\right)$phage P22 and its sensitive host, $S$.

1 This work was supported by U. S. Public Health Service Grant GM-09252-03. typhimurium LT2, are used in these experiments.

Media. (1) Supplemented M-9 (Smith and Levine, 1964); (2) low phosphorus medium (LP medium): Tris $0.07 \mathrm{M} \mathrm{pH} \mathrm{7.3,} \mathrm{NaCl}$ $8.5 \times 10^{-3} M, \mathrm{MgSO}_{4} 2.5 \times 10^{-3} M, \mathrm{NH}_{4} \mathrm{Cl}$ $0.015 M$, glucose $0.2 \%$, peptone (Difeo) $0.05 \%(0.5 \mathrm{mg} \mathrm{P} / 100 \mathrm{ml})$, casamino acids (Difco) $0.2 \%(0.4 \mathrm{mg} \mathrm{P} / 100 \mathrm{ml})$; (3) sodium dodecyl sulfate (SDS), recrystallized from $95 \%$ ethanol, $25 \% \mathrm{w} / \mathrm{v}$; (4) sucrose $5 \%$ and $20 \% \mathrm{w} / \mathrm{v}$ in $0.01 M$ Tris, $0.001 M$ EDTA, pH 7 ; (5) saline-Versene (SV) $0.1 M \mathrm{NaCl}$, $0.1 M$ EDTA, pH 7.9; (6) saline-Tris (ST), $0.145 M$ NaCl, $0.01 M$ Tris $\mathrm{pH} 7.3 ;(7)$ dilute saline-Tris (DST), $1: 10$ dilution of ST; (8) saline-Tris-Versene (STV), ST:SV $=20: 1 ;$ (9) buffered saline (BS), $0.145 M$ $\mathrm{NaCl}, 0.0064 M$ phosphate buffer, $\mathrm{pH} 7$; (10) $\mathrm{NaCl} 4.0 \mathrm{M}$.

Preparation of $P^{32}$-labeled phage PQ2. Salmonella typhimurium LT2 is aerated to $10^{8}$ cells $/ \mathrm{ml}$ in $100 \mathrm{ml} \mathrm{LP}$ medium. One millieurie of $\mathrm{P}^{32}$ is added, and immediately the eulture is infected with phage $\mathrm{P} 22$ at a 
multiplicity of 1-2. After 60 minutes aeration, the culture is treated with chloroform and bacterial debris is removed by centrifugation at $6000 \mathrm{rpm}$ for 30 minutes in the Servall RC-2 centrifuge. The supernatant is aerated free of chloroform and then treated for 30 minutes with DNase $(5 \mu \mathrm{g} / \mathrm{ml})$ and RNase $(50 \mu \mathrm{g} / \mathrm{ml})$ at $37^{\circ}$. The phage is sedimented by centrifugation for 60 minutes at $17,000 \mathrm{rpm}$. The phage pellets are drained, gently resuspended in $2.25 \mathrm{ml} \mathrm{ST}$, and added to a $5 \mathrm{ml}$ Lusteroid tube containing $2.75 \mathrm{ml}$ of $65 \% \mathrm{CsCl}$. The $\mathrm{P}^{32}$-labeled phage is banded by centrifugation at $30,000 \mathrm{rpm}$ in the $\mathrm{SW}$ 39 rotor for $16-18$ hours at $22^{\circ}$ in a Spinco model L-2 ultracentrifuge. Fractions of approximately $0.1 \mathrm{ml}$ are collected through the region of the phage band and assayed for radioactivity. The phage in the tubes of peak radioactivity is combined and diluted appropriately with ST to less than $10^{7}$ $\mathrm{cpm} / \mathrm{ml}$. Labeled phage P22 prepared in this way gives values of $\mathrm{OD}_{260} / \mathrm{PFU} \cong 2 \times$ $10^{-12}$ and $\mathrm{cpm} / \mathrm{PFU} \cong 1.0 \times 10^{-5}$.

Preparation of $\mathrm{H}^{3}$-thymidine-labeled cells and infection with $P^{32}$-labeled phage. Cells are aerated at $37^{\circ}$ in $5 \mathrm{ml}$ supplemented M9 to a concentration of approximately $5 \times$ $10^{7}$ cells $/ \mathrm{ml}$. To this is added $0.05 \mathrm{ml} \mathrm{H}^{3}$ thymidine $(14.2 \mathrm{c} / \mathrm{mmole}, 1 \mathrm{mc} / \mathrm{ml})$. After 2 minutes further aeration, labeling is stopped by addition of $10 \mathrm{mg}$ of unlabeled thymidine. The entire sample is quickly pipetted onto crushed ice in a Millipore filter funnel and filtered at a rate of $1 \mathrm{ml}$ per minute through a $25 \mathrm{~mm}$ Millipore $\mathrm{HA}$ filter $(0.45-\mu$ pore size $)$. The funnel and filter are washed three times with $2-\mathrm{ml}$ aliquots of cold BS. The filter is then added to an aeration tube containing $5 \mathrm{ml}$ BS plus thymidine at a concentration of $100 \mu \mathrm{g} / \mathrm{ml}$, and the cells are resuspended by agitation with a Vortex mixer. Labeled phage is added at a multiplicity of 20 . After 5 minutes adsorption, the infected complexes are filtered as described above, washed with 2 $\mathrm{ml} \mathrm{SV}$, and resuspended in $0.5 \mathrm{ml} \mathrm{STV}$. DNA extracted from these complexes serves as the control (Fig. 1A).

Pulse labeling of DNA synthesized during the course of infection. Log phase cells are aerated at $37^{\circ}$ in supplemented M9 to a concentration of $5 \times 10^{7}$ cells $/ \mathrm{ml}$. Labeled phage is added to a multiplicity of 20 at zero time. A 5-ml aliquot is immediately withdrawn to an aeration tube containing $0.05 \mathrm{ml} \mathrm{H} \mathrm{H}^{3}$-thymidine $(14.2 \mathrm{c} / \mathrm{mmole}, 1$ $\mathrm{mc} / \mathrm{ml}$ ) at $37^{\circ}$. At 2 minutes labeling is stopped by adding $10 \mathrm{mg}$ thymidine and immediately pipetting the entire aliquot onto crushed ice and filtering as described above. After three 2-ml washes with SV, the infected complexes are resuspended in $0.5 \mathrm{ml} \mathrm{STV}$. Additional $5-\mathrm{ml}$ aliquots are pulsed with $\mathrm{H}^{3}$-thymidine at intervals as indicated in Fig. 1.

DNA extraction procedure. A $0.3-\mathrm{ml}$ aliquot of the differentially labeled complexes is added to $0.03 \mathrm{ml}$ of $25 \%$ SDS in a small glass-stoppered tube and placed in a $65^{\circ}$ water bath for 10 minutes. The resulting almost clear lysate is gently mixed by tilting the tube at frequent intervals. The salt concentration is then increased to $1.0 \mathrm{M}$ by addition of $0.1 \mathrm{ml} 4.0 \mathrm{M} \mathrm{NaCl}$. A slight, precipitate quickly dissolves on further gentle mixing as incubation is continued for an additional 10 minutes. The tube is then removed and diluted immediately with 2.0 $\mathrm{ml}$ DST. Mixing is achieved by repeatedly inverting the tube without shaking. The final dilution step achieves three important things: (1) It prevents precipitation of proteins as the temperature is lowered. (2) It decreases the density of the solution below that of $5 \%$ sucrose so that layering on a sucrose gradient is possible. (3) It dilutes the extracted DNA below $1 \mu \mathrm{g} / \mathrm{ml}$ so that aggregation between DNA molecules (Burgi and Hershey, 1963) and/or reassociation with proteins is minimized. The crude DNA preparations should be kept at room temperature. Sucrose gradient patterns remain reproducible for at least 2 weeks, indicating considerable stability and freedom from nuclease activity.

Zone sedimentation on sucrose gradients. Linear $5-20 \%$ sucrose gradients are prepared in 5 -ml tubes using $2.4 \mathrm{ml}$ of $20 \%$ sucrose in the mixing chamber and $2.4 \mathrm{ml}$ of $5 \%$ sucrose in the adjoining chamber (Britten and Roberts, 1960). Over a 15-20second period, about $0.12 \mathrm{ml}$ of the DNA extract is drawn up into a calibrated poly- 

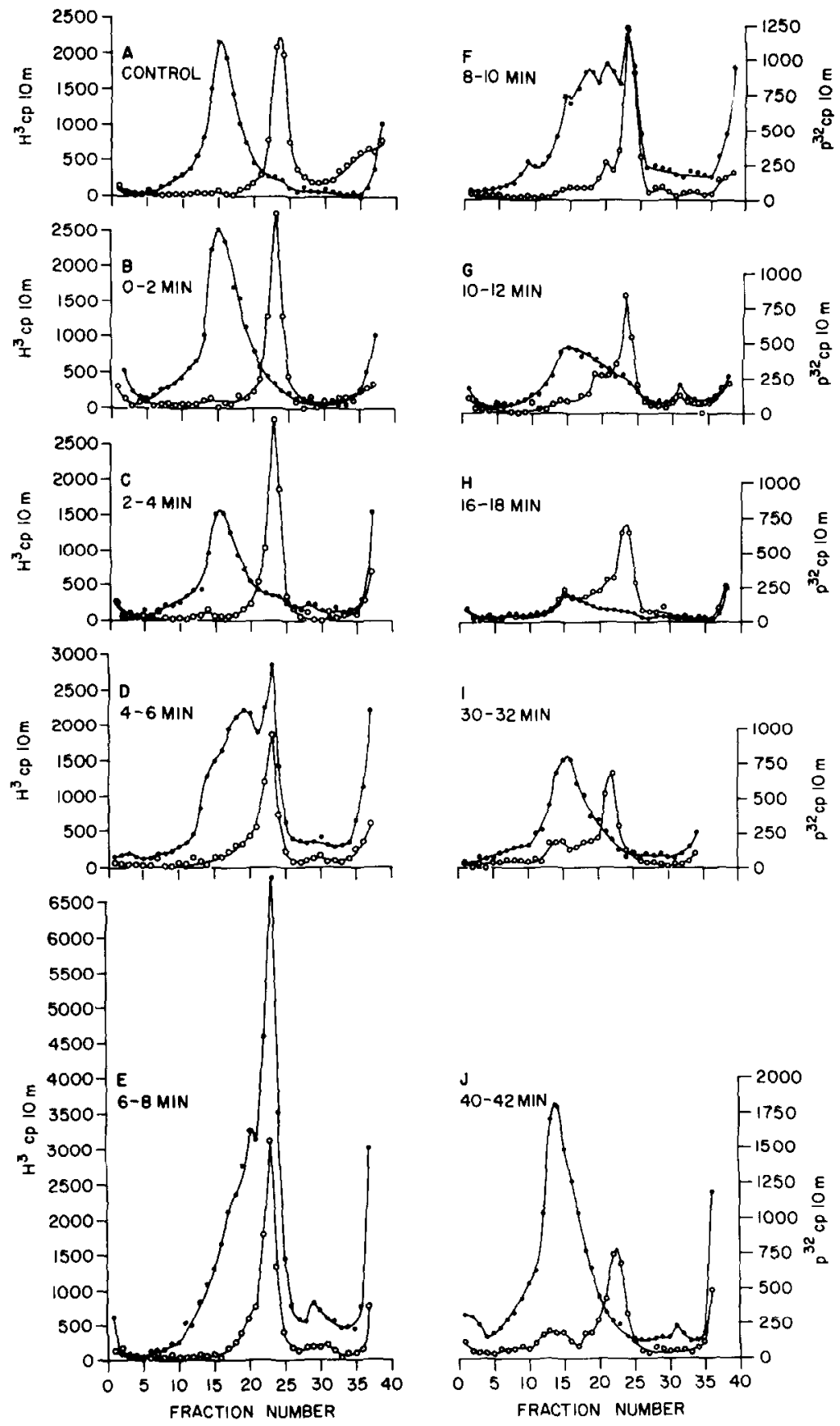

FIG. 1. Separation of the kinds of DNA synthesized at various times during infection leading to lysogeny in the phage P22 Salmonella typhimurium system. $\mathrm{O}-\mathrm{O}-\mathrm{O}$ represents the $\mathrm{P}^{32}$-labeled DNA introduced with the parental phage. - represents the $\mathrm{H}^{3}$-labeled DNA synthesized during the various pulse treatments with $\mathrm{H}^{3}$-thymidine. See text for details. 
ethylene tubing (Clay-Adams, Inc., PE 240, I.D. 0.066 inches) connected to a $1-\mathrm{ml}$ screw-type automatic syringe by manually operating the screw adjustment. The volume is delivered onto the gradient surface at the same rate. All operations are at room temperature.

Zone sedimentation is carried out in the Spinco model L-2 ultracentrifuge using the SW 39 rotor. The preparations are spun at $35,000 \mathrm{rpm}$ for 90 minutes at a rotor temperature of $25^{\circ}$. Approximately 35 ten-drop fractions are collected from the bottom of the centrifuge tube by needle puncture (Szybalski, 1960).

Assay of fractions from sucrose gradients. To each fraction is added $0.3 \mathrm{ml}$ of salmon sperm DNA at $250 \mu \mathrm{g} / \mathrm{ml}$. The tubes are placed on ice and $0.2 \mathrm{ml}$ of TCA $(17 \%$ $\mathrm{w} / \mathrm{v})$ is added. $\Lambda \mathrm{ftcr}$ at least 30 minutes, each precipitated fraction is collected and washed with cold water on Millipore filters to remove any radioactivity not incorporated into DNA. The dried filters are placed in vials containing $10 \mathrm{ml}$ scintillation medium (toluene, 1 liter; PPO, $5 \mathrm{~g}$; POPOP, 100 $\mathrm{mg}$ ) and counted in a Tri-Carb scintillation spectrometer. Recoveries from the sucrose gradient are approximately $60 \%$ for host DNA and $90 \%$ for phage DNA of the total layered on the gradient.

The following factors in the procedure seem eritical for successful separations. (1) The use of elevated temperature is necessary to produce clear lysates. Poor banding occurs from the turbid lysates produced at lower temperatures. (2) DNA extracts yield the most consistent results if allowed to stand at least 18-24 hours at room temperature prior to sedimentation in sucrose. This presumably allows disaggregation of DNA molecules. (3) Cell concentrations should not significantly exceed those described, or DNA aggregation may result in heterogeneous banding and/or sedimentation to the bottom of the tube. (4) Centrifugation at $25^{\circ}$ is essential to good banding in sucrose. Centrifugation at $4^{\circ}$ gives a visible presipitate and sedimentation to the bottom of the tube of most of the labeled DNA.

\section{RLSULTS}

A typical control separation of phaA. DNA from cell DNA is shown in Fig. 1ge Phage DNA bands with a sharp symmetrical peak at fraction 23. Bacterial DNA gives a broader band reaching its peak in fraction 15. There is some tailing of the bacterial DNA band, but the area of overlap with the phage DNA curve is usually not greater than $10 \%$. The curves in Fig. $1 \mathrm{~A}$ serve as references for further comparisons.

Only bacterial DNA is synthesized during the first 4 minutes of the infection (Fig. $1 \mathrm{~B}$ and 1C). Somewhat less bacterial DNA is made during the 2 - to 4-minute interval than in the first 2 minutes. Bacterial DNA continues to be synthesized during the 4-6 minute pulse, but 2 additional species of DNA appear (Fig. 1D). One of these is clearly a peak of newly synthesized phage DNA. The second is a new species which bands between the bacterial and phage peaks. All 3 types of DNA are synthesized through the 6- to 8-minute interval (Fig. $1 \mathrm{E})$, phage DNA being the major type produced. From 8 to 10 minutes, all 3 types continue to be made (Fig. 1F), but the total amount of label fixed decreases sharply. Relatively little DNA is synthesized from 10 to 12 minutes (Fig. 1G), but most of it appears to be bacterial. The synthesis of all three types of DNA is inhibited in the 16- to 18-minute interval (Fig. 1H). From this time on DNA synthesis recovers, but only bacterial DNA is made. The synthesis of phage DNA and the new species which moves in an intermediate position in the gradient remains repressed (Fig. 1I, 1J).

In addition, it should be noted that some of the parental $\mathrm{P}^{32}$-labeled phage DNA undergoes progressive movement from the phage peak to the bacterial peak. This movement begins at the 8th minute and is complete by the 16 th minute.

\section{DISCUSSION}

A unique pattern in the rate of DNA synthesis is observed in infection leading to lysogeny (Smith and Levine, 1964). Immediately on infection, a drop in the rate of DNA synthesis occurs which continues 
until about 3 minutes. The rate of synthesis then rises, reaching a peak at 6 minutes, when another inhibition of DNA synthesis sets in. This repression persists until 16 minutes, at which point the infected complexes show a $90 \%$ inhibition in the rate of synthesis as compared to uninfected control cells. The rate of DNA synthesis then increases until at about 45 minutes it parallels the rate of uninfected control cells. At this time the infected cells begin to divide to produce lysogenic progeny.

In part, this pattern is under the control of two phage genes (Smith and Levine, 1964). This conclusion derives from deviations from this pattern in cells infected with phage mutants $c_{1}$ and $c_{2}$. These phages are virulent mutants unable to give lysogeny, but they cause cell lysis and liberation of progeny phage (Levine, 1957). Mutants of the $c_{1}$ class do not show the inhibition of DNA synthesis at 6 minutes. The rate of phage DNA synthesis continues to rise past 6 minutes, giving lysis and free phage at 25 minutes. On the other hand, $c_{2}$ mutants show the 6-minute inhibition, followed by massive synthesis of phage DNA starting at 16 minutes and lasting until the end of the latent period at 50 minutes. The functions of the $c_{1}$ and $c_{2}$ loci are interpreted as sequential repressions of autonomous phage replication in cells producing lysogenic progeny. Studies involving temperature-sensitive $c_{1}$ and $c_{2}$ mutants substantiate these conclusions (Levine and Smith, 1964).

The data presented in this paper measure directly the relative amounts of phage and host DNA synthesized during a $c^{+}$infection. Phage DNA synthesis starts at about 4 minutes, reaching a peak during the 6to 8-minute interval. A progressive decrease in the amount of phage DNA synthesized follows, until complete repression is reached at 16 minutes. Phage DNA synthesis remains repressed when the synthesis of DNA recovers after the 16 - to 18 -minute interval. These findings confirm our earlier conclusions that the $c_{1}$ locus initiates the repression of phage DNA synthesis and that the $c_{2}$ locus maintains the repression (Smith and Levine, 1964; Levine and Smith, 1964).
Bacterial DNA continues to be synthesized through the early stages of the infection, at what appears to be a decreasing rate, reaching almost complete inhibition by 16 minutes. The recovery of DNA synthesis after 16 minutes in infections leading to lysngeny is accounted for entirely by the synthesis of host material. The genetic control of the repression and subsequent release of host DNA synthesis remains in question. The possibility that the control of host synthesis resides in the phage genome is being explored.

The unexpected finding of a new peak of DNA which moves somewhat faster than phage DNA is of particular interest. This material is synthesized only during the interval in which phage DN $\Lambda$ is made, suggesting that it is a new form of phage DNA. Circular forms of phage $\lambda$ DNA have been reported to sediment somewhat more rapidly than linear forms (Hershey et al., 1963; Young and Sinsheimer, 1964). Campbell has suggested that integration of the $\lambda$ prophage proceeds through a circular form of $\lambda$ DNA. The material in the new peak could be an integrative form. The observed movement of input parental phage $\mathrm{P}^{32}$ label from the phage peak into the bacterial peak also suggests that some integration of phage genetic material into the host genome occurs around the 16th minute of the infection. That most of the $\mathrm{P}^{32}$ label transfer to the host peak occurs during the interval of maximum repression of DNA synthesis strongly suggests that this is not due to simple breakdown and reincoorporation. These findings are currently being studied.

\section{REFERENCES}

Britten, R. J., and Rober's, R. B. (1960). Highresolution density gradient sedimentation analysis. Science 131, 32-33.

Burai, E., and Henshey, A. D. (1963). Sedimenta tion rate as a measure of molecular weight of DNA. Biophys. J. 3, 309-321.

Hershey, $\Lambda$. D., Bungi, E., and Ingrailam, L. (1963). Cohesion of DNA molecules isolated from phage lambda. Proc. Natl. Acad. Sci. U.S. 49, 748-755.

Levine, M. (1957). Mutation in the temperate 
phage P22 and lysogeny in Salmonella. Virology 3, $22-41$.

Levine, M., and Smith, H. O. (1964). Sequential gene action in the establishment of lysogeny. Science 146, 1581-1582.

Smith, H. O., and Levine, M. (1964). Two sequential repressions of DNA synthesis in the establishment of lysogeny by phage P22 and its mutants. Proc. Natl. Acad. Sci. U.S. 52, 356363.

SZYBaLSKI, W. (1960). Sampling of virus particles and macromolecules sedimented in an equilibrium density gradient. Experientia 16, 164. Young, E. T., and Sinsheimer, R. L. (1964). Novel intra-cellular forms of lambda IDNA. $J$. Mol. Biol. 10, 562-564. 